\title{
PERANAN PENDIDIKAN DAN PRODUKTIVITAS SEKTOR PERTANIAN TERHADAP PENURUNAN TINGKAT KEMISKINAN DI JAWA TENGAH
}

\author{
Rully Sutansyah Effendy \\ Badan Pusat Statistik Jawa Tengah \\ Email : rully111@gmail.com
}

\begin{abstract}
Abstrak
Kemiskinan merupakan permasalahan yang mendasar dalam pembangunan ekonomi, terutama pada Negara berkembang seperti Indonesia. Jawa Tengah menjadi salah satu provinsi yang selalu memiliki tingkat kemiskinan di atas level nasional. Metode analisis yang digunakan untuk mengetahui faktor-faktor yang mempengaruhi kemiskinan di Jawa Tengah digunakan analisis regresi data panel. Estimasi dilakukan dengan metode random effect model. Nilai koefisien determinasi (Adjusted $R$-square) untuk model diperoleh angka sebesar 0,728 yang menunjukkan bahwa variabel bebas di dalam model mampu menjelaskan 73 persen variasi variabel endogen secara baik. Sementara, 27 persen sisanya dijelaskan oleh variable lainnya yang berada di luar model. Pendidikan, produktivitas sector pertanian dan inflasi memiliki pengaruh terhadap penurunan tingkat kemiskinan. Pengangguran dan pertumbuhan ekonomi berpengaruh positif terhadap tingkat kemiskinan.
\end{abstract}

Kata kunci : Tingkat kemiskinan, Regresi data panel, Model efek random

\begin{abstract}
Poverty is a fundamental problem in economic development, especially in developing countries like Indonesia. Central Java became one of the provinces that have always had poverty rates above the national level. The analytical method used to determine the factors that affect poverty in Central Java used panel data regression analysis. Estimation was conducted using a random effect model. The coefficient of determination (Adjusted $R$-square) to model the figure of 0.728 which indicates that the independent variable in the model is able to explain 73 percent of the variation of endogenous variables as well. Meanwhile, 27 percent of the rest is explained by other variables that are outside the model. Education, agricultural productivity and inflation have an impact on poverty reduction. Unemployment and economic growth positive effect on poverty levels.
\end{abstract}

Keywords: Poverty rates, Panel data regression, Random effects model 


\section{PENDAHULUAN}

Kemiskinan merupakan permasalahan yang mendasar dalam pembangunan ekonomi, terutama pada negara berkembang seperti Indonesia. Jumlah penduduk miskin di Indonesia pada bulan Maret 2015 mencapai 28,59 juta orang (11,22 persen), bertambah sebesar 0,86 juta orang dibandingkan dengan kondisi
September 2014 yang sebesar 27,73 juta orang atau 10,96 persen (BPS, 2015).

Kemiskinan di Indonesia merupakan agregat dari kondisi kemiskinan yang ada di daerah. Pulau Jawa merupakan salah satu pulau di Indonesia dengan jumlah penduduk miskin terbesar. Jumlah penduduk miskin di Pulau Jawa 15,45 juta jiwa dari 28,59 juta jiwa jumlah penduduk miskin di Indonesia pada Maret 2015.

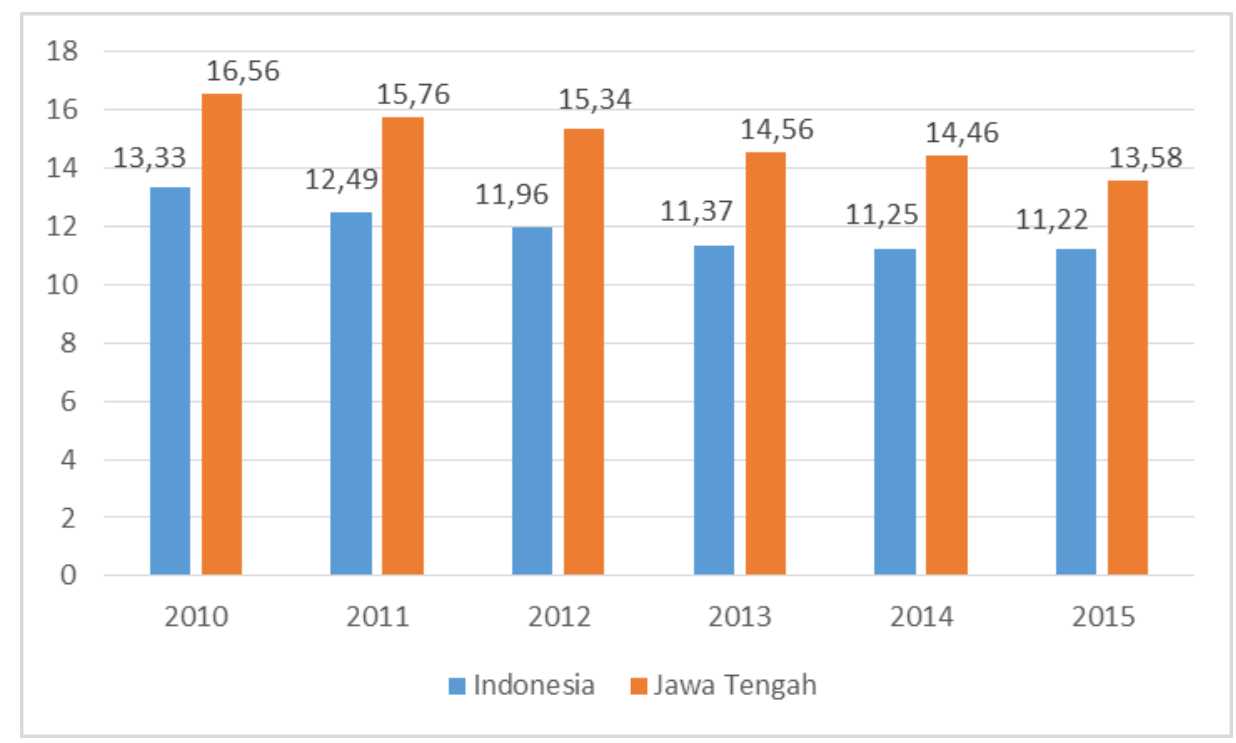

Gambar 1. Tingkat kemiskinan di Indonesia dan Jawa Tengah 2010-2015 (persen)

Salah satu provinsi yang memiliki permasalahan kemiskinan yang cukup kompleks adalah Jawa Tengah. Berdasarkan data BPS, Jawa Tengah menjadi salah satu provinsi yang selalu memiliki tingkat kemiskinan (Head Count Index/HCI) di atas level nasional dan memiliki populasi penduduk miskin (Head Count/HC) terbanyak kedua secara nasional. Data tingkat kemiskinan di Jawa Tengah pada Maret 2015 tercatat sebesar 13,58 persen atau mencapai 4,57 juta orang miskin, naik 15,21 ribu orang jika dibandingkan dengan penduduk miskin pada September 2014 yang sebesar 4,56 juta orang (Gambar 1).

Jumlah penduduk miskin Provinsi Jawa Tengah pada Maret 2015 tercatat sebanyak 4,57 juta jiwa sementara penduduk miskin secara nasional sebanyak 28,59 juta jiwa,berarti sebanyak 16 persen dari populasi penduduk miskin Indonesia terdapat di Jawa Tengah. Hal ini berarti upaya Pemerintah untuk mengatasi kemiskinan belum mencapai target yang direncanakan yakni sebesar 8,75 persen.

Permasalahan kemiskinan di Jawa Tengah yaitu tingkat kemiskinan yang tinggi di atas sasaran $M D G s$ dan Rencana Pembangunan Jangka Menengah (RPJM), serta penurunan kemiskinannya berjalan lambat. Dalam periode 2010-2015 persentase tingkat kemiskinan di Provinsi Jawa Tengah selalu lebih besar dibandingkan level nasional, Gambar 1. Dalam $M D G s$, penanggulangan kemiskinan dan kelaparan menjadi tujuan pertama target pembangunan. Target yang ingin dicapai adalah menurunkan angka kemiskinan hingga 50 persen pada tahun 2015 dengan didasarkan pada angka kemiskinan tahun 1990. Pada tahun 1990 
angka kemiskinan di Indonesia sebesar 15,10 persen, maka pada tahun 2015 diharapkan menjadi 7,50 persen (sekitar 13,10 juta penduduk).

Keseriusan pemerintah dalam upaya mencapai target penurunan kemiskinan tercantum dalam RPJM 2010-2014 yang menunjukkan bahwa salah satu sasaran pembangunan ekonomi nasional adalah mempercepat penurunan tingkat kemiskinan hingga 8-10 persen pada akhir 2014, sehingga diharapkan pada tahun 2015 target $M D G s$ bisa tercapai. Pencapaian target $M D G s$ dan Rencana Pembangunan Jangka Panjang (RPJP) di level Provinsi Jawa Tengah sampai tahun 2015 masih jauh di atas sasaran secara nasional. Tingkat kemiskinan selama periode 20102015 belum mencapai sasaran. Apabila dibandingkan dengan kinerja ekonomi Jawa Tengah yang mampu tumbuh di atas 5 persen tiap tahun pada periode 20102015, maka penurunan kemiskinan dinilai berjalan jauh lebih lambat.

Inflasi di Jawa Tengah selama 20102015 cukup fluktuatif. Selama periode 2010-2015 inflasi tertinggi mencapai 8,22 persen di tahun 2014 dan terendah tercatat pada tahun 2011 yaitu sebesar 2,68 persen (BPS). Secara teoritis penanggung terberat inflasi adalah mereka yang berpendapatan tetap dan kaum penganggur (yang tidak memiliki pendapatan). Menurut data BPS, sekitar $70-80 \%$ pendapatan orang miskin digunakan untuk mengkonsumsi pangan, sedangkan penyumbang utama inflasi adalah komoditas pangan.

Menurut Easterly dan Fischer (2001) inflasi menjadikan penduduk miskin menjadi semakin miskin. Inflasi yang rendah dan stabil merupakan prasyarat bagi pertumbuhan ekonomi yang berkesinambungan, dalam rangka meningkatkan kesejahteraan masyarakat. Kemiskinan menggambarkan kondisi ketiadaan kepemilikan dan rendahnya pendapatan, atau secara lebih rinci menggambarkan suatu kondisi tidak dapat terpenuhinya kebutuhan dasar manusia, yaitu pangan, papan, dan sandang.
Menurut BPS, kemiskinan diartikan sebagai ketidakmampuan individu dalam memenuhi kebutuhan dasar minimal untuk hidup layak.

Pemerataan pendapatan dan pengentasan kemiskinan menjadi salah satu prioritas pembangunan ekonomi di Indonesia. Salah satu visi RPJP yang ingin diwujudkan pada periode 2005-2025 adalah mewujudkan pemerataan pembangunan yang berkeadilan melalui pengurangan kesenjangan sosial secara menyeluruh, serta penanggulangan kemiskinan. Pembangunan ekonomi ditujukan untuk memperkuat struktur perekonomian dengan mendudukkan sektor industri sebagai motor penggerak yang didukung oleh kegiatan pertanian dan pertambangan yang efisien, serta kegiatan jasa yang efektif.

Peningkatan kesejahteraan penduduk dilakukan dengan memberi perhatian yang lebih besar pada kelompok penduduk yang kurang beruntung, terutama penduduk miskin. Pemenuhan hak-hak dasar, seperti pekerjaan yang layak, perlindungan hukum, rasa aman, kebutuhan hidup pendidikan, kesehatan, keadilan, politik dan beragama.

Kemiskinan memiliki banyak definisi, dan sebagian besar sering mengaitkan konsep kemiskinan dengan aspek ekonomi. Besarnya kemiskinan dapat diukur dengan atau tanpa mengacu kepada garis kemiskinan (poverty line) (Todaro, 2006). Konsep yang mengacu kepada garis kemiskinan disebut kemiskinan absolut, sedangkan konsep yang pengukurannya tidak didasarkan pada garis kemiskinan disebut kemiskinan relatif. Kemiskinan absolut adalah derajat kemiskinan di bawah, di mana kebutuhankebutuhan minimum untuk bertahan hidup tidak dapat terpenuhi. Sedangkan kemiskinan relatif berkaitan dengan kesenjangan di dalam distribusi pendapatan.

Berdasar penyebabnya, Kartasasmita (1996) membagi kemiskinan menjadi dua yaitu kemiskinan kultural dan kemiskinan 
struktural. Kemiskinan kultural mengacu pada sikap seseorang atau masyarakat yang disebabkan oleh gaya hidup, kebiasaan hidup dan budayanya. Kemiskinan struktural disebabkan karena perolehan pendapatan yang tidak seimbang, sebagai akibat dari keadaan kepemilikan sumber daya yang tidak merata, kemampuan yang tidak seimbang, serta ketidaksamaan kesempatan dalam berusaha dan memperoleh pendapatan.

Banyak faktor yang bisa menyebabkan kemiskinan, baik yang berasal dari individu, keluarga, maupun kondisi sosial ekonomi dimana individu berada. Studi tentang rumah tangga miskin di sejumlah negara dengan latar belakang yang berbeda telah mengungkapkan ciriciri kemiskinan dengan cukup konsisten. Menurut Green dan Hulme (2005) dalam Adji dan Listiyani (2008) rumah tangga miskin adalah rumah tangga dengan angka ketergantungan yang tinggi, kepemilikan aset yang terbatas, kurangnya akses terhadap berbagai sumber pendapatan dan mungkin mengalami kerugian sosial. Faktor-faktor tersebut secara terus menerus menyebabkan dan berdampak pada kemiskinan, yang terwujud secara nyata dalam bentuk penyakit, kekurangan gizi, buta huruf dan ketidakmampuan untuk mengakses kebutuhan barang dan jasa yang sangat mendasar.

Tingkat pertumbuhan ekonomi yang dicapai oleh suatu negara diukur dari perkembangan pendapatan nasional riil yang dicapai suatu negara/daerah. Pertumbuhan ekonomi terkait dengan pendapatan per kapita, yang berarti berhubungan dengan dua hal yaitu total output (PDRB) dan jumlah penduduk. Menurut Tarmizi (2014) PDRB memiliki pengaruh signifikan terhadap jumlah penduduk miskin.

Menurut Gounder (2013), pendidikan tinggi, kebijakan yang mendukung pertanian di wilayah rural, dan realokasi tenaga kerja ke sektor formal merupakan langkah efektif untuk mengurangi kemiskinan.
Menurut The National Anti-Poverty Strategy (NAPS 1999), pengangguran merupakan penyebab terbesar terjadinya kemiskinan di Irlandia dimana terdapat keterkaitan yang sangat kuat antara pengangguran dengan kemiskinan. Pada tahun 1994, lebih dari setengah dari total keluarga di Ireland dipimpin oleh kepala keluarga yang tidak mempunyai pekerjaan. Menurut Waluyo (2012) jumlah pengangguran turut mengurangi efektivitas pengentasan kemiskinan.

Siregar dan Wahyuniarti (2007) dalam penelitiannya "Dampak Pertumbuhan Ekonomi Terhadap Penurunan Jumlah Penduduk Miskin" menghasilkan temuan bahwa peningkatan jumlah populasi penduduk sebesar 1000 orang akan meningkatkan jumlah penduduk miskin sebanyak 249 orang. Menurut Arsyad (2010), satu faktor penyebab kemiskinan di sektor pertanian adalah rendahnya produktivitas di sektor tersebut dan hal ini salah satunya disebabkan oleh distribusi lahan pertanian yang semakin timpang. Produktivitas pertanian dan jumlah pekerja sektor pertanian memiliki hubungan positif dengan jumlah penduduk miskin (Suwandi, 2011). Sekitar 64,65 persen penduduk miskin bekerja pada sektor pertanian pada bulan Maret 2009 (BPS).

Permasalahan dalam penelitian ini adalah tingkat kemiskinan di Jawa Tengah yang tinggi, di atas tingkat kemiskinan nasional. Beberapa faktor yang diduga memiliki pengaruh terhadap tingkat kemiskinan menurut studi terdahulu adalah inflasi, laju produk domestik regional bruto (PDRB), tingkat pendidikan, pengangguran, laju pertumbuhan jumlah penduduk, dan produktivitas sektor pertanian.

\section{METODE PENELITIAN}

Data yang digunakan dalam penelitian ini adalah data yang diperoleh dari Badan Pusat Statistik (BPS) serta data-data lainnya yang relevan dengan penelitian. Data yang digunakan antara 
lain data persentase jumlah penduduk miskin, inflasi, pertumbuhan ekonomi, tingkat pengangguran terbuka, tingkat pendidikan yang dipresentasikan dengan rata-rata lama sekolah, laju pertumbuhan jumlah penduduk, dan produktivitas sektor pertanian, antara tahun 2010 sampai dengan 2015.

Metode analisis yang digunakan untuk mengetahui faktor-faktor yang mempengaruhi kemiskinan di Jawa Tengah digunakan analisis panel data. Pengolahan data dilakukan dengan program Eviews 9. Salah satu bentuk struktur data yang sering digunakan dalam studi ekonometrika adalah data panel. Penggunaan data panel dimaksudkan untuk mengkombinasikan antara data cross section dan data time series sehingga jumlah observasi menjadi banyak. Marginal effect dari peubah penjelas dapat dilihat dari dua dimensi, yaitu individu dan waktu sehingga parameter yang diestimasi akan lebih akurat dibandingkan dengan model lain.

Di antara sekian banyak kegunaan dari data panel, salah satu manfaat paling banyak dirasakan oleh para ahli ekonomi adalah penggunaan data panel mengatasi masalah kekurangan data yang tidak dapat dipenuhi oleh data time series. Selain itu data semacam ini memiliki keunggulan terutama karena bersifat robust terhadap beberapa pelanggaran asumsi Gauss Markov, yakni heteroskedastisitas dan normalitas (Wooldridge dalam Ariefianto, 2012). Penelitian mengenai pengaruh inflasi, pertumbuhan ekonomi, tingkat pendidikan, pengangguran, laju pertumbuhan jumlah penduduk produktivitas sektor pertanian yang digunakan dalam model penelitian ini adalah sebagai berikut:

$$
\begin{gathered}
Y_{i t}= \\
\beta_{0+}+\beta_{1} X_{1 i t}+\beta_{2} X_{2 i t}+\beta_{3} X_{3 i t}+ \\
\begin{array}{c}
\beta_{5} X_{5 i t}+\beta_{6} X_{6 i t}+\varepsilon_{i t} \\
\text { merupakan variabel Tingkat }
\end{array}
\end{gathered}
$$

Kemiskinan, $\beta_{0}$ adalah Konstanta/Intersep, $X_{l}$ adalah Inflasi, $X_{2}$ adalah Pertumbuhan Ekonomi, $\quad X_{3}$ adalah Rata-rata Lama Sekolah penduduk 25 tahun ke atas, $X_{4}$ adalah Tingkat Pengangguran Terbuka, $X_{5}$ adalah Laju Pertumbuhan Jumlah Penduduk, $X_{6}$ adalah Produktivitas Sektor Pertanian, dan $\varepsilon$ adalah komponen Error.

\section{HASIL DAN PEMBAHASAN}

Pemilihan model regresi terbaik dilakukan untuk mendapatkan hasil estimasi yang baik. Proses ini dilakukan dalam dua tahap, yaitu membandingkan pooled model dengan fixed effects model kemudian dilanjutkan dengan membandingkan fixed effects model dengan random effect model. Penghitungan estimasi parameter model dilakukan menggunakan bantuan perangkat lunak Eviews 9. Pada tahap pertama, digunakan Uji Chow, untuk membandingkan pooled model dengan fixed effects model, sedangkan pada tahap kedua, digunakan Uji Hausman, untuk membandingkan fixed effects model dengan random effect model.

Berdasarkan hasil uji Chow, secara signifikan Ho (pooled model) ditolak atau terdapat heterogenitas individu pada model. Ini ditunjukkan nilai Prob. Crosssection $\mathrm{F}$ sebesar 0,0000 yang nilainya < 0,05sehingga dapat disimpulkan bahwa model Fixed Effect lebih tepat dibandingkan dengan model Common Effect.

Setelah dihasilkan fixed effects model pada langkah pertama, maka langkah selanjutnya membandingkan antara fixed effects model dan random effects model dengan uji Hausman. Statistik uji Hausman mengikuti distribusi statistik Chi-Square dengan derajat bebas sebanyak jumlah variabel bebas.

Hasil uji Hausman menunjukkan nilai probabilitas Period random nilainya 0.2432 lebih besar dari0,05 maka model yang terpilih adalah RE. Hal ini berarti persamaan faktor-faktor yang mempengaruhi kemiskinan memiliki heterogenitas individu secara random. Dengan demikian random effects model lebih sesuai digunakan.

Asumsi yang harus dipenuhi dalam persamaan regresi adalah varian error 
harus sama dengan $\sigma^{2}$ (konstan), atau semua error mempunyai varian yang sama yang disebut dengan homoskedastisitas. Nilai Sum Square Resid model weighted dan unweighted : $0,386207<13,60951$, artinya sisaan bersifat homoskedastisitas (varians konstan) / tidak heteroskedastisitas pada model.

Selanjutnya uji normalitas dilakukan dalam model. Uji normalitas digunakan untuk menguji apakah residual mengikuti distribusi normal atau tidak. Hasil estimasi menunjukkan model faktor-faktor yang memengaruhi kemiskinan mempunyai nilai residual berdistribusi normal, berdasarkan nilai probabilitas JarqueBera. Nilai probabilitas Jarque-Bera 0.104426 lebih besar dari 0,05 sehingga dapat diperoleh kesimpulan nilai residual berdistribusi normal.
Setelah dilakukan pengujian dan diperoleh model dan metode yang paling sesuai, maka dilakukan estimasi dari persamaan tersebut. Estimasi dilakukan dengan metode random fixed effect. Estimasi dilakukan untuk mengetahui besarnya elastisitas dari setiap variabel bebas (independent variable) terhadap variabel tidak bebas (dependent variable). Variabel tidak bebas yaitu tingkat kemiskinan penduduk, sedangkan variabel bebas meliputi inflasi, pertumbuhan ekonomi, rata-rata lama sekolah, tingkat pengangguran terbuka, laju pertumbuhan jumlah penduduk, dan produktivitas pekerja sektor pertanian. Berikut disajikan hasil estimasi faktor-faktor yang memengaruhi kemiskinan di Provinsi Jawa Tengah pada Tabel 1.

\begin{tabular}{|c|c|c|c|}
\hline \multirow[t]{2}{*}{ Varlabel bebas } & \multicolumn{3}{|c|}{ Varlabel tldak bebas: tingkat kemlskinan } \\
\hline & Koeflsien & SE & Slgnifikansl \\
\hline $\bar{E}$ & 4,773334 & 0,197303 & \\
\hline INF & $-0,00 \in 880$ & 0,001366 & $\cdots$ \\
\hline GROW & 0,011230 & $0,005 \in 03$ & 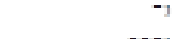 \\
\hline MYs & $-0,8 \operatorname{sg} 43$ & 0,117662 & $\cdots$ \\
\hline TFT & 0,009716 & 0,002384 & $\cdots$ \\
\hline $\mathrm{FOF}$ & $-0,003922$ & 0,014128 & \\
\hline PDTV & $-0,165681$ & 0,019512 & $\cdots$ \\
\hline Adusted R Square & 0,723364 & & \\
\hline Prob (F-statistlc) & 0.000000 & & \\
\hline
\end{tabular}

Keterangan: *) : signifikan pada taraf 1 persen

***) : signifikan pada taraf 10 persen

Hasil estimasi menunjukkan nilai probabilitas F-statistik < 0,01 dan ini dapat diartikan bahwa variabel-variabel bebas pada model mampu menjelaskan keragaman tingkat kemiskinan pada taraf nyata $(\alpha) 1$ persen. Artinya, minimal terdapat satu variabel bebas yang secara nyata memengaruhi variabel tak bebas tingkat kemiskinan. Nilai koefisien determinasi (Adjusted R-square) untuk model diperoleh angka sebesar 0,728 yang menunjukkan bahwa variabel bebas di dalam model mampu menjelaskan 73 persen variasi variabel endogen secara baik. Sementara, 27 persen sisanya dijelaskan oleh variabel lainnya yang berada di luar model.
Arah dan besarnya pengaruh dari setiap variabel bebas dapat diketahui menggunakan pengujian secara parsial dengan uji t. Pengujian parameter model (koefisien persamaan) menggunakan uji $\mathrm{t}$ menunjukkan empat variabel bebas yang berada dalam model secara nyata memengaruhi tingkat kemiskinan pada taraf 1 persen, satu variabel dalam model secara nyata memengaruhi tingkat kemiskinan pada taraf 10 persen, dan ada satu variabel yang tidak secara nyata mempengaruhi tingkat kemiskinan yaitu laju pertumbuhan penduduk.

Empat variabel bebas yang memiliki pengaruh dengan arah negatif terhadap variabel tak bebas tingkat kemiskinan 
adalah inflasi, rata-rata lama sekolah, laju pertumbuhan penduduk, dan produktivitas sektor pertanian. Sementara dua variabel bebas memiliki pengaruh dengan arah positif terhadap variabel tak bebas tingkat kemiskinan yaitu pertumbuhan ekonomi dan tingkat pengangguran.

\section{Pengaruh Inflasi Terhadap Tingkat Kemiskinan}

Berdasarkan output hasil pengolahan, variabel inflasi memiliki koefisien sebesar -0,006. Angka ini memiliki makna setiap kenaikan inflasi sebesar satu persen akan menurunkan tingkat kemiskinan sebesar 0,006 persen dengan asumsi variabel yang lainnya bersifat konstan (ceteris paribus). Hasil ini seolah-olah bertentangan dengan teori dan beberapa studi yang pernah dilaksanakan sebelumnya. Namun, jika dikaji lebih mendalam dalam hasil ini sejalan dengan dampak dari inflasi. Inflasi memiliki dampak positif dan dampak negatif tergantung parah atau tidaknya inflasi. Apabila inflasi itu ringan, justru mempunyai pengaruh yang positif dalam arti dapat mendorong perekonomian lebih baik, yaitu meningkatkan pendapatan nasional dan membuat orang bergairah untuk bekerja, menabung dan mengadakan investasi. Selama rentang periode 20102015, inflasi di Provinsi Jawa Tengah berada pada level 2,68 persen sampai 7,99 persen. Artinya, inflasi di Provinsi Jawa Tengah kurang dari 10 persen, termasuk dalam inflasi ringan. Inflasi rendah dan terkendali dapat mendorong perekonomian lebih baik.

\section{Pengaruh Pertumbuhan Ekonomi Terhadap Tingkat Kemiskinan}

Nilai koefisien variabel pertumbuhan ekonomi dalam model hasil estimasi menggunakan REM tercatat sebesar 0,011. Angka ini bermakna setiap kenaikan nilai tambah bruto atau pertumbuhan ekonomi sebesar 1 persen akan meningkatkan tingkat kemiskinan 0,011 persen dengan asumsi variabel bebas yang lain bersifat konstan (ceteris paribus).

Temuan penelitian ini dapat dijelaskan oleh fenomena distribusi manfaat hasil pertumbuhan 2011-2014 di Provinsi Jawa Tengah lebih banyak dinikmati oleh penduduk pada golongan pendapatan tertinggi. Secara implisit hal ini menggambarkan manfaat pertumbuhan ekonomi di Jawa Tengah lebih banyak dinikmati oleh penduduk golongan berpendapatan atas atau pertumbuhan tidak bersifat pro poor.

\section{Pengaruh Rata-rata Lama Sekolah Terhadap Tingkat Kemiskinan}

Berdasarkan output hasil pengolahan variabel rata-rata lama sekolah memiliki pengaruh terbesar terhadap penurunan tingkat kemiskinan. Koefisien variabel rata-rata lama sekolah penduduk sebesar 0,88 . Angka ini memiliki makna setiap kenaikan rata-rata lama sekolah sebesar satu persen akan menurunkan tingkat kemiskinan sebesar 0,88 persen dengan asumsi variabel yang lainnya bersifat konstan (ceteris paribus). Hasil ini sejalan dengan beberapa penelitian sebelumnya seperti Siregar dan Wahyuniarti (2008), De Silva (2008), Wahyuni (2011), Gounder (2013) yang menyatakan pendidikan akan mengurangi tingkat kemiskinan.

Rata-rata lama sekolah penduduk di Provinsi Jawa Tengah selama periode 2010-2015 mengalami peningkatan, dari 6,7 tahun pada 2010 menjadi 7,03 tahun pada 2015. Dibanding provinsi-provinsi lainnya di Pulau Jawa angka rata-rata lama sekolah di Jawa Tengah adalah yang terendah. Peningkatan rata-rata lama sekolah penduduk menurunkan tingkat kemiskinan di Provinsi Jawa Tengah.

\section{Pengaruh Pengangguran Terhadap Tingkat Kemiskinan}

Hasil penelitian memperlihatkan bahwa pengangguran memiliki pengaruh signifikan pada peningkatan jumlah penduduk miskin di Provinsi Jawa Tengah. Tingkat elastisitas pengangguran sebesar 0,009 yang artinya peningkatan pengangguran sebesar 1 persen akan meningkatkan tingkat kemiskinan sebesar 0,009 persen, ceteris paribus. Hasil penelitian ini sejalan dengan beberapa penelitian sebelumnya, antara lain: 
Sukirno (2004), Suparno (2010), dan Wahyuni (2011) yang menyatakan bahwa peningkatan pengangguran menyebabkan peningkatan kemiskinan.

Pengangguran menjadi beban perekonomian, dimana mereka tidak menghasilkan pendapatan namun secara rutin mengeluarkan biaya guna memenuhi kebutuhan hidupnya. Untuk memenuhi kebutuhannya mereka menggunakan hasil kerja orang lain, sehingga mengurangi pendapatan perkapita. Jika pendapatan perkapita menurun akibatnya tingkat kesejahteraan juga menurun dan kemiskinan meningkat. Pengangguran akan berpengaruh pada nasib generasi berikutnya. Jika dalam suatu rumah tangga banyak anggota rumah tangga yang menganggur atau bekerja dengan gaji rendah, maka rumah tangga tersebut akan mengalami kesulitan dalam memenuhi kebutuhan rumah tangganya secara layak dan memadai. Kondisi ini akan menggiring mereka hidup dalam kemiskinan. Karena pengangguran menjadi penyebab kemiskinan, maka masalah pengangguran harus segera diatasi. Salah satu cara yang harus ditempuh untuk menurunkan pengangguran adalah dengan meningkatkan pertumbuhan ekonomi. Secara teori, peningkatan pertumbuhan ekonomi akan diikuti dengan peningkatan jumlah lapangan pekerjaan. Lapangan pekerjaan yang tercipta akan memperbesar peluang para penganggur untuk bekerja sehingga tidak menganggur lagi.

\section{Pengaruh Produktivitas Sektor Pertanian Terhadap Tingkat Kemiskinan}

Berdasarkan hasil estimasi, nilai koefisien produktivitas sektor pertanian adalah $-0,165$ pada taraf nyata 1 persen, yang memiliki makna bahwa peningkatan produktivitas sektor pertanian 1 persen akan menurunkan tingkat kemiskinan sebesar 0,165 persen, ceteris paribus. Hasil ini mengindikasikan bahwa pembangunan di sektor pertanian perlu ditingkatkan. Sektor pertanian menjadi andalan dalam menghasilkan nilai tambah maupun dalam menyerap angkatan kerja di daerah perdesaan. Lapangan usaha ini juga menjadi harapan utama bagi pengentasan kemiskinan perdesaan maupun penanggulangan persoalan ketimpangan pendapatan.

Hasil penelitian ini sesuai dengan teori pembangunan yang menyebutkan bahwa sektor pertanian merupakan penggerak pembangunan (engine of growth) baik dari segi penyedian bahan baku, kesempatan kerja, bahan pangan, serta sebagai daya beli bagi produk yang dihasilkan oleh sektor lain. Secara alamiah pembangunan harus didukung oleh berkembangnya sektor pertanian yang kuat baik segi penawaran maupun dari segi permintaan. Dengan kuatnya sektor pertanian dipandang dari sisi penawaran maupun di sisi permintaan maka pertanian akan mampu mendukung dan membuat jalinan dengan sektor kegiatan ekonomi lain. Penelitian Tian et al. (2003), Suwardi (2011), Hermawan (2012) menunjukkan hasil yang sejalan yaitu pertumbuhan produktivitas pertanian memiliki dampak yang signifikan terhadap pengurangan kemiskinan.

\section{PENUTUP \\ Simpulan}

Hasil penelitian menggunakan regresi data panel dengan model terpilih metode REM menunjukkan bahwa inflasi, pertumbuhan ekonomi, pendidikan, pengangguran, laju pertumbuhan penduduk, dan produktivitas sektor pertanian secara bersama-sama memiliki pengaruh terhadap tingkat kemiskinan di Provinsi Jawa Tengah.

Tingkat pendidikan yang direpresentasikan dengan variabel rata-rata lama sekolah serta produktivitas sektor pertanian menjadi dua faktor determinan utama dalam menurunkan tingkat kemiskinan. Pendidikan merupakan sarana meningkatkan kualitas sumber daya manusia untuk menghasilkan tenaga kerja yang lebih produktif. Produktivitas sektor pertanian yang tinggi akan menjadi pen- 
dorong peningkatan output dan daya beli masyarakat.

Pengangguran memiliki hubungan positif dengan tingkat kemiskinan. Hasil ini mempunyai implikasi bahwa ketersediaan lapangan pekerjaan sangat dibutuhkan agar mereka dapat bekerja dan mempunyai pendapatan rutin untuk memenuhi kebutuhan hidupnya, sehingga dapat keluar dari kemiskinan.

\section{DAFTAR PUSTAKA}

Adji, A. \& Listiyani, N. S. (2008). Karakteristik Sosio-Demografi Kemiskinan Kronis Di Indonesia. Jurnal Ekonomi Indonesia. (2),1-32.

Ariefianto, M. D. (2012). Ekonometrika Esensi dan Aplikasi dengan Menggunakan Eviews. Jakarta: Penerbit Erlangga.

Arsyad, L. (2010). Ekonomi Pembangunan. Edisi 5. Yogyakarta: Penerbit UPP STIM YKPN.

Badan Pusat Statistik. (2007-2015). Statistik Indonesia 2007-2015. Jakarta: Badan Pusat Statistik.

Badan Pusat Statistik. (2007-2015). Data dan Informasi Kemiskinan 20072015. Jakarta: Badan Pusat Statistik.

Badan Pusat Statistik. (2015). Berita Resmi Statistik No. 86/09/Th.XVIII,15 September 2015. Jakarta: Badan Pusat Statistik.

Badan Pusat Statistik. (2015). Berita Resmi Statistik No. 66/09/33/Th.IX,15 September 2015. Semarang: Badan Pusat Statistik Provinsi Jawa Tengah.

Easterly, W. \& Fischer, S. Inflation and the Poor. Journal of Money, Credit, and Banking; May 2001; 33(2).
Gounder, N. (2013). Correlates of Poverty in Fiji An Analysis of Individual, Household and Community Factors Related to Poverty. International Journal of Social Economics. 40(10), 923-938.

Gujarati, D. (2006). Dasar-dasar Ekonometrika, Edisi Ketiga. Jakarta: Penerbit Erlangga.

Harianto. (2008). Kebijakan Harga Pangan yang Efektif Semakin Diperlukan untuk Mengatasi Kemiskinan. Jurnal Ekonomi Indonesia. 2, 139-154.

Hariyanto. (2010). Pertumbuhan Ekonomi, Kemiskinan, dan Ketimpangan di Daerah Penghasil Migas. Tesis. Bogor. Sekolah Pascasarjana Institut Pertanian Bogor. http://repository.ipb.ac.id/ handle/123456789/41047.

Hermawan, I. (2012). Analisis Eksistensi Sektor Pertanian terhadap Pengurangan Kemiskinan di Pedesaan dan Perkotaan. Jurnal MIMBAR. 28(2), 135-144.

Jhingan, M.L. (2003). Ekonomi Pembangunan dan Perencanaan. Penerjemah: D. Guritno. Jakarta: PT Raja Grafindo Persada.

Kakwani, N. S. K. \& Son, H.H. (2004). Pro-Poor Growth: Concepts and Measurement with Country Case Studies.United Nations Development Programme International Poverty Centre. 1.

Kartasasmita, G. (1996). Pembangunan Untuk Rakyat; Memadukan Pertumbuhan dan Pemerataan. Jakarta: CIDES. 
Lucas, R.E.B. (1997). Handbook of Family and Economics Internal Migration in Developing Countries, ed. M. R. Rosenzweig and Stark. Boston: Elseviere-Science Press, 721-78

NAPS. (1999). Unemployment and Poverty. Poverty Briefing No 7 Unemployment and Poverty. Poverty Agency.

Papilaya, E.C. \& Sugihen, B.G. (2006). Akar dan Strategi Pengentasan Kemiskinan di Kota Ambon, Maluku dan Kabupaten Balemo, Gorontalo. Jurnal Penyuluhan. 2(4).

Rahman, R.I. (2006). Access to Education and Employment: Implications for Poverty. PRCPB Working Paper No. 14. Bangladesh Institute of Development Studies (BIDS). Dhaka, Bangladesh.

Sayogyo. (1982). Garis Kemiskinan dan Kebutuhan Minimum Pangan: Mencari Bentuk Ekonomi Indonesia, Perkembangan Pemikiran 19651980. Jakarta: PT Gramedia.

Siregar, H \& Wahyuniarti, D. (2007). Dampak Pertumbuhan Ekonomi terhadap Penurunan Jumlah Penduduk Miskin. $M B-I P B$.

Siregar, H \& Masyitho, S. (2008). Dinamika Harga Pangan, BBM, Inflasi serta Kemiskinan, dan Implikasinya Bagi Ketahanan Pangan. Jurnal Ekonomi Indonesia. 2.

Smeru. (2001). Paket Informasi Dasar: Penanggulangan Kemiskinan. Disusun untuk Badan Koordinasi Penanggulangan Kemiskinan (BKPK). Agustus 2001.
Suwardi, A. (2011). Pengeluaran Pemerintah Daerah, Produktivitas Pertanian, dan Kemiskinan di Indonesia. Jurnal Ekonomi dan Pembangunan Indonesia. 12(1), 3955.

Tarmizi, H.B. (2014). An Analysis of Influencing Factors on Poverty in Sustainability Development Framework: A Case in Deli Serdang Regency, Indonesia. Journal of Economics and Behavioral Studies. 6(7), 581-590.

Tian, W., Xiuqing, W., \& Fuyan, K. (2003). Poverty Alleviation Role of Agriculture in China. ROA/FAO, International Conference, Italy.

Todaro, M.P. \& Smith, S.C. (2006). Pembangunan Ekonomi. Jilid 1. Edisi 9. Alih Bahasa. Jakarta: Penerbit Erlangga.

Wahyuni, S. (2011). Kemiskinan dan Kebijakan Penanggulangannya di Kawasan Barat dan Timur Indonesia. Tesis. Bogor. Sekolah Pascasarjana Institut Pertanian Bogor. http://repository. ipb.ac.id/handle/123456789/57254

Waluyo. (2012). The Linkage Between Growth, Unemployment and Income Inequality on Poverty in Central of Java Province, 2004-2010. Tesis. Bogor. Sekolah Pascasarjana Institut Pertanian Bogor. http://repository.ipb.ac.id/ handle/123456789/61553

World Bank. (2002). World Development Indicators. The World Bank. Washington.

World Bank. (2005). Attaining the Millennium Development Goals in Bangladesh, Human Development Unit, South Asia Region. 
World Bank. (2006). Era Baru dalam Pengentasan Kemiskinan di Indonesia. Ikhtisar. The World Bank, Jakarta.

Yudhoyono, SB. (2004). Pembangunan Pertanian dan Perdesaan sebagai Upaya Mengatasi Kemiskinan dan Pengangguran: Analisis Ekonomi Politik Kebijakan Fiskal. Disertasi. Sekolah Pasca Sarjana Institut Pertanian Bogor. Bogor. 